
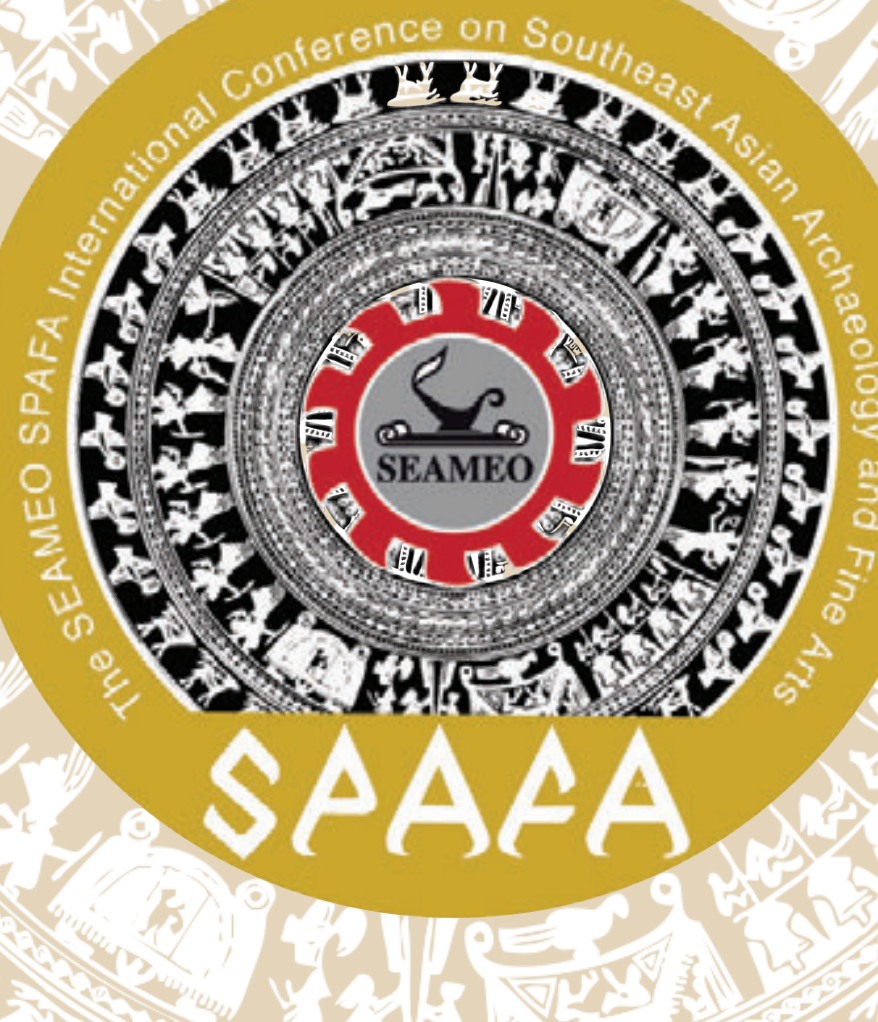
SPAFACON2021 is published by SEAMEO SPAFA, the Regional Centre for Archaeology and Fine Arts established by the Southeast Asian Ministers of Education Organization. SEAMEO SPAFA focusses on archaeology and fine arts in Southeast Asia, and promotes awareness and appreciation of the cultural heritage of the region. Its member-countries are Brunei, Cambodia, Indonesia, Lao PDR, Malaysia, Myanmar, the Philippines, Singapore, Thailand, Timor-Leste, and Vietnam; and its associate member-countries are Australia, Canada, France, Germany, the Netherlands, New Zealand, Spain and the United Kingdom. 


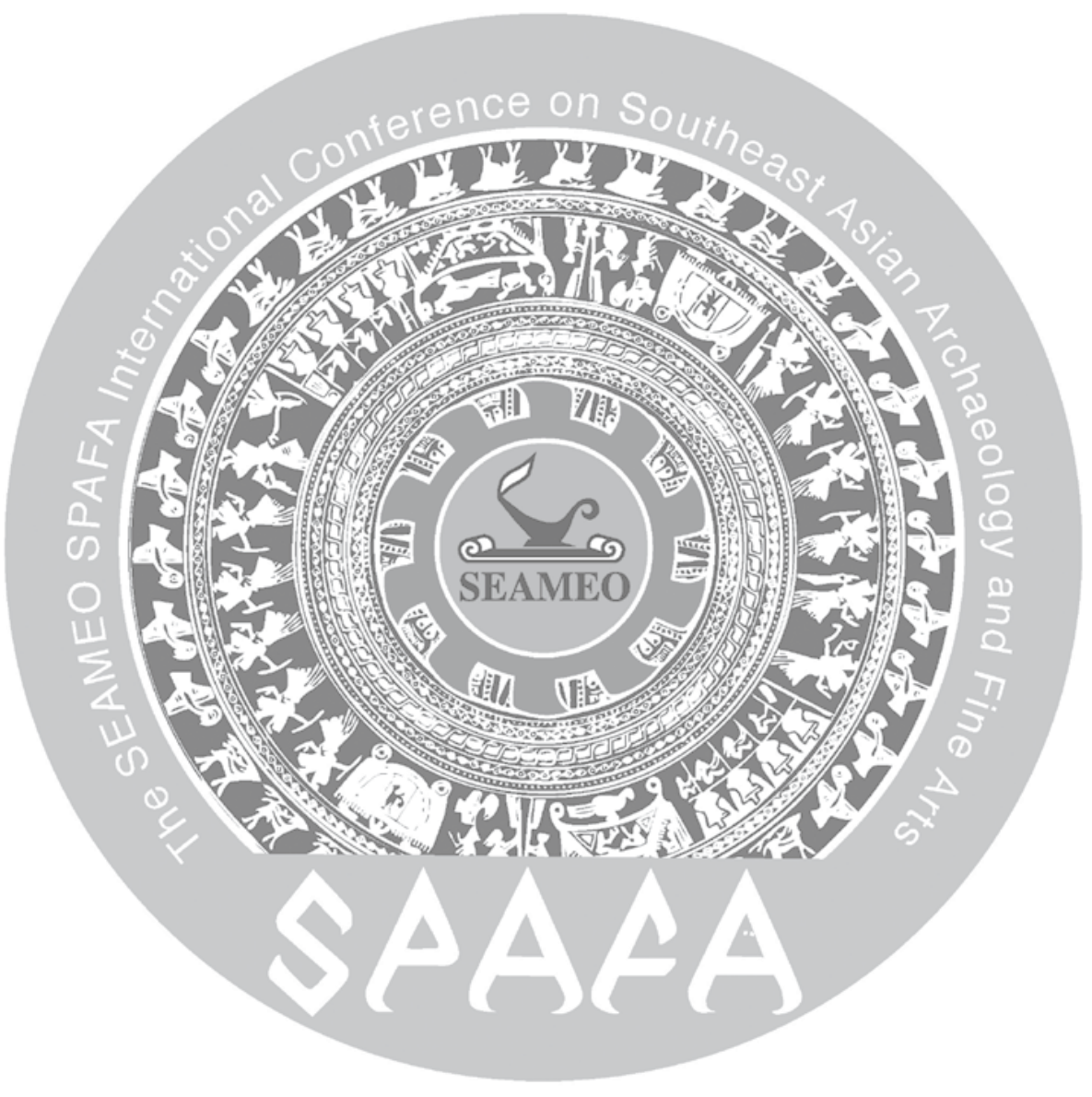

SPAFACON2021

Papers from the SEAMEO SPAFA International Conference on SOUTHEAST ASIAN ARCHAEOLOGY AND FINE ARTS

13 - 17 December 2021

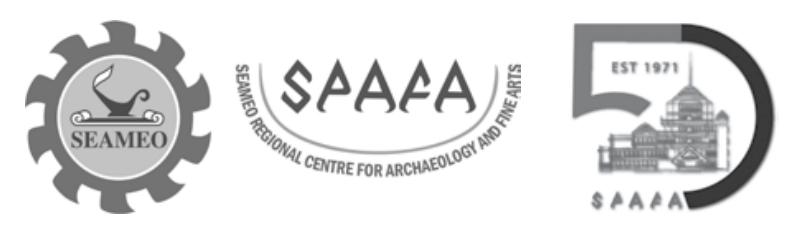


2021 SEAMEO SPAFA

ISBN: 978-616-7961-55-2

ISBN (e-book): 978-616-7961-54-5

DOI 10.26721/spafa.pqcnu8815a

\section{Publisher}

SEAMEO SPAFA Regional Centre for Archaeology and Fine Arts

81/1 Sri Ayutthaya Road, Dusit

Bangkok 10300, Thailand

Tel: +66 (0) 22804022 to 9

Fax: +66 (0) 22804030

www.seameo-spafa.org

E-mail: spafa@seameo-spafa.org

\section{Editor}

Dr Noel Hidalgo Tan

\section{Organizing Committee}

Mrs Somlak Charoenpot

Ms Vassana Kerdsupap

Mr Kanal Khiev

Mr Ean Lee

Ms Gabrielle Anne Mangaser

Dr Hatthaya Siriphatthanakun

Ms Ratchaporn Tesjeeb

Mr Patrick Xia Linhao

Dr Noel Hidalgo Tan

\section{(c) (1) (2)}

Copyright in the volume as a whole is vested in SEAMEO SPAFA, and copyright in the individual chapters also belong to their respective authors and licensed under Creative Commons CC BY-SA 4.0. To view a copy of this license, visit https://creativecommons. org/licenses/by-sa/4.0/

The papers in this publication have not been peer-reviewed and may thus contain preliminary findings, errors, or information that has yet to be endorsed by the relevant academic community. The views expressed in the publication do not necessarily reflect the opinions or policies of SEAMEO SPAFA. 


\section{Title}

\section{CONTENT}

\begin{tabular}{|c|c|c|}
\hline Title & Author & Page \\
\hline \multicolumn{3}{|l|}{ Introduction } \\
\hline $\begin{array}{l}\text { A Historiography of Settlement Archaeology in Southeast } \\
\text { Asia, with Emphasis on the Pre-industrial State Formations }\end{array}$ & Gyles Iannone & 1 \\
\hline $\begin{array}{l}\text { Ocean Imperatives: analysing shipping infrastructure for the } \\
\text { study of maritime networks in Southeast Asia }\end{array}$ & Veronica Walker Vadillo & 17 \\
\hline $\begin{array}{l}\text { Forms of government and local community participation in } \\
\text { the management of cultural World Heritage sites in Southeast } \\
\text { Asia }\end{array}$ & Vithaya Arporn & 24 \\
\hline $\begin{array}{l}\text { Cultural interaction between Việt Nam and Southeast Asian } \\
\text { nations in the } 15^{\text {th }}-16^{\text {th }} \text { centuries: An overview of pottery } \\
\text { items from ancient shipwrecks on display at the Museum of } \\
\text { History in Hồ Chí Minh City }\end{array}$ & $\begin{array}{l}\text { Phạm Ngọc Uyên, } \\
\text { Nguyễn Thị Tú Anh }\end{array}$ & 29 \\
\hline $\begin{array}{l}\text { Sequential Least-Cost Path Sailing Model for Early } 17^{\text {th }} \\
\text { Century South China Sea: Digitally Navigating the Selden } \\
\text { Map of China }\end{array}$ & Wesa Perttola & 40 \\
\hline $\begin{array}{l}\text { The Prevailing Art and Tradition of Intentional Dental } \\
\text { Modification in Prehistoric Southeast Asia }\end{array}$ & Maria Kathryn N. Purnell & 56 \\
\hline $\begin{array}{l}\text { The Still Unexplored Parts of Southeast Asian Archaeology: } \\
\text { Colonial Archaeology Singapore }\end{array}$ & Sxuann Sim & 74 \\
\hline $\begin{array}{l}\text { Khao San Dam: The Archaeological Evidence of Burnt Rice } \\
\text { Festival in Southern Thailand }\end{array}$ & Pakpadee Yukongdi & 83 \\
\hline $\begin{array}{l}\text { Before Bagan: Using Archaeological Data Sets to Assess the } \\
\text { Traditional Historical Narrative }\end{array}$ & $\begin{array}{l}\text { Scott Macrae, Gyles } \\
\text { Iannone, Kong Cheong, } \\
\text { Pyiet Phyo Kyaw }\end{array}$ & 96 \\
\hline The Rock Art in Kinta Valley, West Malaysia: A synthesis & $\begin{array}{l}\text { Chaw Yeh Saw } \\
\text { Hsiao Mei Goh }\end{array}$ & 114 \\
\hline $\begin{array}{l}\text { New Archaeological Discoveries: Gates and Turrets of } 16^{\text {th }} \\
\text { Burmese Royal Capital of Hamsāvatī }\end{array}$ & Thaw Zin Latt & 131 \\
\hline $\begin{array}{l}\text { A preliminary survey of Chinese ceramics in Champa } \\
\text { archaeological sites }\end{array}$ & Do Truong Giang & 148 \\
\hline $\begin{array}{l}\text { A Study on the Structure and Significance of the North } \\
\text { Sanctuary at Western Prasat Top }\end{array}$ & $\begin{array}{l}\text { SATO Yuni, TAMURA } \\
\text { Tomomi, SUGIYAMA } \\
\text { Hiroshi, LAM Sopheak, } \\
\text { SOK Keo Sovannara, } \\
\text { LOEUNG Ravattey, ROS } \\
\text { Visoth }\end{array}$ & 166 \\
\hline The funeral cave of Laang Spean & $\begin{array}{l}\text { Valéry Zeitoun, } \\
\text { Heng Sophady, Hubert } \\
\text { Forestier }\end{array}$ & 173 \\
\hline
\end{tabular}




\begin{tabular}{|c|c|c|}
\hline Title & Author & Page \\
\hline $\begin{array}{l}\text { The Bronze Age People of Ban Kao: A Preliminary Analysis } \\
\text { of the Human Remains from Ban Ta Po Archaeological Site, } \\
\text { Western Thailand }\end{array}$ & $\begin{array}{l}\text { Naruphol } \\
\text { Wangthongchaicharoen, } \\
\text { Supamas Duangsakul, } \\
\text { Pira Venunan, Sukanya } \\
\text { Lertwinitnun, Siriyupon } \\
\text { Tubpenthai }\end{array}$ & 187 \\
\hline The Mt. Popa Watershed and Bagan's Bronze-Iron Age & Elizabeth Moore & 195 \\
\hline $\begin{array}{l}\text { After } 30 \text { Years and During a Pandemic: Pottery Production } \\
\text { and Distribution in Bagacay, Talibon in the Island of Bohol in } \\
\text { the Philippines }\end{array}$ & $\begin{array}{l}\text { Rhayan Gatbonton } \\
\text { Melendres }\end{array}$ & 205 \\
\hline $\begin{array}{l}\text { Heritage Education in Myanmar - developing resilience and } \\
\text { sustainability through community engagement }\end{array}$ & $\begin{array}{l}\text { Su Su, Win Thant Win } \\
\text { Shwin, Ohnmar Myo, } \\
\text { Charlotte Galloway, } \\
\text { Elizabeth Moore }\end{array}$ & 220 \\
\hline $\begin{array}{l}\text { As my father said: Traditional boatbuilding in Pasuruan, East } \\
\text { Java }\end{array}$ & $\begin{array}{l}\text { Agni Mochtar, Putri } \\
\text { Taniardi, R. Ahmad } \\
\text { Ginanjar Purnawibawa }\end{array}$ & 234 \\
\hline $\begin{array}{l}\text { Tangibility-Intangibility on UNESCO World Heritage } \\
\text { Baroque Philippine Churches: the Spirit of Place and Its } \\
\text { Collective Memory }\end{array}$ & Hee Sook Lee-Niinioja & 241 \\
\hline $\begin{array}{l}\text { Myinkaba village Bagan: The Resilience of Traditional } \\
\text { Knowledge and Culture }\end{array}$ & Theint Aung & 254 \\
\hline $\begin{array}{l}\text { Thai Carpentry Knowledge Transmission: Development of } \\
\text { Traditional Apprenticeships in a New Context }\end{array}$ & Nichamon Hiranpruek & 262 \\
\hline $\begin{array}{l}\text { The Factors of Market Success and Failure of Contemporary } \\
\text { Artists from ASEAN countries }\end{array}$ & Dr Rémy JARRY & 268 \\
\hline $\begin{array}{l}\text { The Forgotten Women: Investigating the Absence of the } \\
\text { Female Artist from Traditionally Male-Centric Southeast } \\
\text { Asian Contemporary Art Historical Narratives }\end{array}$ & Vasanth Narayanan & 279 \\
\hline As One With Nature: Southeast Asian Aesthetic Expressions & Victor R. Savage & 289 \\
\hline $\begin{array}{l}\text { The Series Of Archaeological Dances: A Historical Study and } \\
\text { Dance Moves Recording With Labanotation }\end{array}$ & Dharakorn Chandnasaro & 309 \\
\hline $\begin{array}{l}\text { Musical Instruments on the 16th century bas reliefs in } \\
\text { the North Gallery-East Wing of Angkor Wat : Dating and } \\
\text { Significance }\end{array}$ & Arsenio Nicolas & 324 \\
\hline $\begin{array}{l}\text { Photography in Indonesian Archaeology of the } 19^{\text {th }} \text { to the } \\
\text { Early } 20^{\text {th }} \text { Century }\end{array}$ & $\begin{array}{l}\text { Ahmad Kholdun Ibnu } \\
\text { Sholah }\end{array}$ & 356 \\
\hline $\begin{array}{l}\text { Old Burmese weights were not opium weights. They were } \\
\text { weights. What else do we know about them? }\end{array}$ & Bob Hudson & 369 \\
\hline $\begin{array}{l}\text { Religious Object" Exhibition in the Context of Cultural } \\
\text { Change and Covid-19 Social Distancing (Case studies of } \\
\text { Khmer's Nagar boat in the South of Vietnam) }\end{array}$ & Phạm Thị Thủy Chung & 381 \\
\hline
\end{tabular}




\section{Title}

Author

Page

Creativity and Innovation in Cultural Heritage Management in Plunturan Village, Pulung District, Ponorogo Regency,

Ria Kusuma Wardani, S.Pd.

East Java Province of Indonesia Towards Tourism Village

Beyond the artefact : promoting technology

Cécile de Francquen 407

Indonesian Museum after New Order Regime: The

Representation that Never Disappears

Ayu Dipta Kirana, Fajar

Aji Jiwandono

Geological Museum Innovations to Dealing with Covid-19 Ifan Yoga Pratama Suharyogi, Agustina Djafar, Rahajeng Ayu

Pandemic 


\section{INTRODUCTION}

This volume contains the extended abstracts from the papers presented at the SEAMEO SPAFA International Conference on Southeast Asian Archaeology and Fine Arts, which was held online from 13 to 17 December 2021. Also known as the SPAFACON2021, this conference was organised online due to the pandemic. Despite the disruption brought about by Covid-19 to our in-person events, training programmes and field research, it is heartening to see that archaeology and cultural heritage has continued under new modes of communication and collaboration.

This fourth iteration of the SPAFACON is also scheduled a year earlier than our usual triennial cycle to commemorate the 50th anniversary of SEAMEO initiating a centre dedicated towards archaeology and the fine arts. Over the past year, SPAFA has also been highlighting this legacy of international cooperation and capacity-building by sharing our photographic archives on our social media.

I am delighted by the high level of enthusiasm and intellectual curiosity brought by the participants to the conference. During our call for papers we received close to 90 submissions, but owing to the pressures of time and the online format, we were only able to accept 34 papers for the conference. The variety of papers present here, although a small set compared with our usual proceedings, reflects the breadth of the centre's ambit covering not just archaeology, but also performing arts, visual arts, museum studies, and other aspects of Southeast Asian cultural heritage.

I would like to thank all the participants, without whom this conference would not be possible in its present form, in particular, our Governing Board members who represent every country in Southeast Asia, and to the Ministry of Culture, Thailand and the Ministry of Education, Thailand for their long-standing support of SEAMEO SPAFA and its activities.

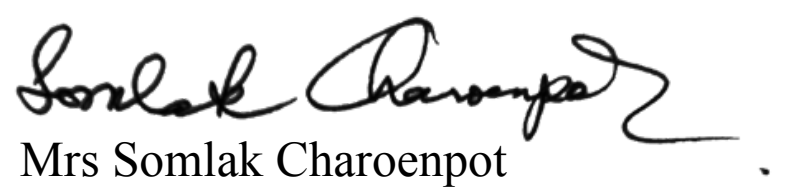

Centre Director

SEAMEO SPAFA 


\title{
Ocean Imperatives: analysing shipping infrastructure for the study of maritime networks in Southeast Asia
}

\author{
10.26721/spafa.pqcnu8815a-02 \\ Veronica Walker Vadillo \\ University of Helsinki, Faculty of Arts, \\ Department of Cultures, Archaeology; Helsinki, Finland \\ veronica.walker@helsinki.fi
}

\begin{abstract}
How did Southeast Asia transform from a hub of prehistoric coastal networks into a transregional interdependent port system by the early modern period? To answer this question, which is crucial to understanding the historical developments of polities along the IndoPacific r egion, this presentation proposes to examine the synergetic nature of shipping infrastructure in order to push current boundaries that place the focus on trade goods.
\end{abstract}

\section{Keywords}

maritime archaeology, nautical archaeology, infrastructure, environment, ships, South China Sea, historical ecology, human ecodynamics

\section{Introduction}

Maritime networks conform an interdependent system where every piece must interlock to the others like a well-oiled machine. The environment determines when ports are accessible, the depth of ports determines the size and number of ships that can be serviced, and the size of ships determines the requirements of wharf storage facilities and stevedore crews. All this requires specialized skills and intellectual ingenuity that develops around navigation, stevedoring, and the construction of infrastructures to overcome environmental hurdles.

Using an interdisciplinary approach that draws on environmental, archaeological, iconographic, ethnographic, and historical data, this presentation will explore shipping logistics and infrastructure as a novel source material to advance a new research framework that incorporates methods rooted in geographically oriented landscape perspectives, such as the Maritime Cultural Landscape, and ecological approaches like Historical Ecology, and Human Ecodynamics. This additional turn of the screw offers an innovative understanding of the role of maritime networks in the history of the region by looking at the past from the water, and seeking out the ocean imperatives that shaped how people moved seamlessly through oceans, seas, and rivers. 


\section{Shipping infrastructure as a source of data}

If we want to understand past maritime landscapes, we need to study the material remains related to human activities on the seas, interconnected waterways, adjacent locales and associated communities. These include, but are not limited to harbours, ports, navigation and sailing routes, place-names, lighthouses, shipyards, fishing harbours, and so on. This approach, coined by Westerdahl (1992) as the maritime cultural landscape, recognizes the plurality of maritime landscapes as they respond to functionality within maritime communities, so some can be linked to transport, others to surveillance, to fishing, to spirituality and pilgrimages, and so on. Whatever the focus, ships remain at the forefront as enablers of these interactions between humans and their watery environment.

The versatility of this theoretical framework lies in the interdisciplinary approach that requires, and the long-term perspective that demands from the set out of the research design. This is very much in line with other environmental approaches like Human Ecodynamics (Fitzhugh et al. 2019) and Historical Ecology (Crumley 2006), both of which recognize the importance of providing a chronological depth to the analysis, emphasize the importance of a geographic and ecological perspective, and require the use of a variety of sources that are available for different periods of time. Depending on the time scope, the range of data that can be used may come from environmental sciences, archaeology, history, ethnography, iconography, and so on (see Fitzhugh et al. 2019).

With this idea in mind, instead of focusing on maritime networks as an intangible concept that connects people through the study of mobile material remains, the Ports and Harbours of Southeast Asia project has placed the focus on shipping infrastructure as the tangible evidence of this connectivity. An emphasis on the functional aspects of the network, the role of the environment, and the interdependence of these elements throughout the network sets the tone of the analysis.

\section{Shipping as an entangled system: a view from recent history}

As Mark Levinson exposed in his 2007 seminal book The Box: How the Shipping Container Made the World Smaller and the World Economy Bigger, maritime trade networks conform an entangled ecosystem where every piece must interlock to the others like a well-oiled machine (2007: XXX). Compatible conditions must be present along the network so that a ship can pick up cargo in Guangzhou, stop to load and unload cargo in Singapore, cross the Suez Canal and unload goods in Barcelona before it makes its return trip loaded with items to be sold in the East. Maritime networks therefore sit at the intersection between the environment, the ports, and the ships, and they are meaningful only in relation to each other. 
The interdependent shipping system we have today is relatively new ${ }^{1}$. In 1956 the world did not look the way it looks today. Our pantries were filled with products that were made and sold locally, the beef we ate was raised and slaughtered close by, and the clothes we wore did not carry labels stating that they were made in long distant countries. Snapshots of busy ports depicted a world in chaos, where large crews of stevedores, which are workers specialized in loading and unloading cargo, carried sacks of goods on their back as trucks struggled to move in and out of the busy streets. The waterfront was made up of low-cost housing buildings for dockworkers, competing against ever-increasing needs for larger storage facilities. Close by, manufacturing plants were busy making goods, close enough to the ports so that the finished product could be shipped at the lowest possible cost in order to get as much profit as possible.

On April $26^{\text {th }} 1956$ the wheels were set in motion to change the world forever, as the first modified tanker ship made its way from Newark to Houston loaded with the first container boxes ever used. Humble in its appearance, the container box lead the way to globalization by improving the shipping ecosystem. The process of loading and unloading cargo was optimized, the prices to carry goods over long distances was drastically reduced, and the world economy took full advantage of the new opportunities that these changes brought in. For better or worse, workers worldwide saw their livelihoods altered forever as factories were split and relocated, whilst everyday products became cheaper.

What is interesting from this example is not so much how the world has changed, which is a fascinating subject on its own, but what it took for the world to change, as this is where we can better grasp the complexity of ships and shipping. After initial tests, it took more than four decades to establish the box container as the main means of cargo transport (Levinson 2006). Changing the system in such a radical way required major investments and overhauls of port infrastructures, ships, trucks, and trains (Ibid.). These changes were not only required at a national level, but also needed adjustments on a trans-national level. It was not enough for the port of New York to change, or for the ports of the U.S.'s East Coast to share the same system. For the system to work, it required other parties to join the network. Many different stakeholders, including various groups of unionized stevedores, port authorities, city halls, land transport companies, railway companies, and state agents had to be coordinated if the system was to be implemented, again, not only within the port, but also within the state, and across borders (Levinson 2006: 54-126).

1 The next two paragraphs are a summary of chapters 1 and 2 of Levinson (2006) The Box: how the shipping container made the world smaller and the world economy bigger. 
Prior advances in nautical technology and hydraulic engineering had optimized the network to reduce the time of journeys. The canals of Suez and Panama had helped reduce time travel, whereas the development of steam ships in the $19^{\text {th }}$ century allowed us to break free from wind patterns. While ships were getting bigger and faster, the dimensions of the canals of Suez and Panama constrained their size, and continues to do so in today's world. Other improvements that were set out before the advent of the box container included the adoption of the standardized time zones we have today. Before that, each city adjusted their time according to the sun (Bonikowsky 2015), which created scheduling issues for navigation and made shipping unreliable. A worldwide system of time zones was promoted in 1884 during the International Meridian Conference, but was not globally applied by the majority of countries until 1929. So once again, these efforts toward standardization involved lengthy processes of negotiation with multiple stakeholders (see Bonikowsky 2015).

Despite these difficulties, the introduction of these innovations contributed to the eventual success of modern shipping infrastructure, a port system so interdependent that when the pandemic hit in early 2020 the disruption of the supply chain threw the world in disarray, and continues to do so in the first months of 2021 (Walker Vadillo 2020). This entanglement was further felt worldwide when, in March 24th 2021, the global economy came to a halt as one of the largest container ships in the world, the Ever Given, was hit by high winds and a sand storm, lost control of its engines and ended up stuck across the Suez canal. The ship disrupted traffic through the canal and created an unprecedented maritime traffic jam that is still having economic repercussions today (Schiffling and Valantasis Kanellos 2021a). It is yet unknown whether the incident can be attributed to human or technical error, but as Schiffling and Valantasis Kanellos point out, vessels may simply be outgrowing the maritime infrastructure (2021b).

What becomes apparent in this new age of shipping is that ships and ports do not exist independently, but in co-existence. They are entangled to such a point that change requires involving multiple stakeholders in ongoing conversations that take decades to conclude. This system is in constant evolution. Concerns over climate change and the desire to be fossil-fuel free is paving the way to the incorporation of alternative fuels (Watson, Farley \& Williams 2021), whereas the introduction of fully automated ships using new technologies is currently being explored and it is estimated that it will take decades to see any changes in this direction (Biltoo et al. 2019). Furthermore, the Ever Given incident has exposed the fragility of such an interdependent system to the point that there are now suggestions to scale down the operations and invest in more sustainable and resilient 
short supply chains, especially in light of current environmental challenges (Schiffling and Valantasis Kanellos 2021a).

\section{Archaic globalization and shipping infrastructure}

The example presented above may seem out of place in archaeology, but it is brought forth to highlight what the past was not. Never in the history of humankind have we been so interdependent, and as connected to each other as we are today. This interconnectedness is what the term "globalization" often refers too, and is inextricably linked to that which enables said connectivity: transport systems (see Held and McGrew 2000: 1-3). Hence, by studying the way shipping systems developed and changed over time, we can begin to understand how peoples and cultures interacted with each other, and how (or to what level) globalization was achieved in the pre-modern world.

To conduct this analysis, maritime connectivity has to be understood through the physical remains of the infrastructure system that made shipping possible. Infrastructure is materialized as a cluster of physical structures that require a certain degree of labour organization that exceeds the household level, and involves further efforts to preserve and maintain its functionality (Wilkinson 2019: ). These elements can exist without a state, but as pointed out by Wilkinson, their relevance increases as societies become more state-like (2019: 1221). Because the ultimate function of infrastructure is to move other matter, the individual elements of the network need not only be analysed on their own merit, but also in relation to the whole (see Larkin 2013: 329). In this way, infrastructure is as much an addition of material elements, as it is a relation between these elements, and when they operate in conjunction, they become systems (Ibid.).

When discussing shipping infrastructure on these terms, a nuance should be made to reflect the strong impact that the environment has on shipping systems. Earth systems, such as weather patterns, wind and ocean currents, as well as other, less considered elements such as aquatic resources, also plays a vital role in shipping, especially in regards to intergenerational knowledge acquisition, navigation, and timing/periodicity. As Ingold pointed out, "to inhabit the open is not to be stranded on the outer surface of the earth but to be caught up in the transformation of the weather-world" (Ingold 2007: S20). Referring to maritime connectivity as networks seems to evoke a two-dimensional perception of the world, and fails to recognize that the world is in a constant state of flux (Ingold 2007: S28). Adding the layer of the Earth Systems to the analysis transforms this network into a meshwork, term coined by Ingold (2015), that better reflects the three dimensional reality of shipping. 


\section{Conclusion}

The aim of this presentation was to reflect on the nature of maritime connectivity and direct our attention to shipping infrastructure as a valid source of archaeological and historical inquiry. A contemporary example of how increasing complexity of shipping infrastructure paved the road to higher interdependence worldwide was set forth to highlight the role of shipping in globalization processes. This paper contends that, by gaining a better understanding of the affordances and constraints of shipping infrastructure in the past (that is, ocean imperatives) we can find new ways of studying archaic globalization in Southeast Asia. Finally, the paper proposes to analyse shipping infrastructure as a meshwork where individual objects and environmental elements are examined in relation to each other. This approach will allow us to get a better grasp of the shipping system that enabled longdistance interactions in Southeast Asia and neighbouring regions, thus paving the way to increased interconnectedness and, eventually, to globalization.

\section{References}

Biltoo, M, Chatfield, C, Newberry, D and West, R (2019) Adoption of fully automated shipping will take decades, not years. Kennedys Law. Available at: https://kennedyslaw.com/news/adoption-of-fully-automated-shipping-will-takedecades-not-years/ [accessed 17 September 2021].

Bonikowsky, LN (2015) Invention of Standard Time. The Canadian Encyclopedia. Available at: https://www.thecanadianencyclopedia.ca/en/article/invention-ofstandard-time-feature [accessed 17 September 2021].

Crumley, C (2006) Historical ecology: integrated thinking at multiple temporal and spatial scales. In: A Hornborg and C Crumley (eds.) The World System and the Earth System: global socioenvironmental change and sustainability since the neolithic. London, New York: Routledge.

Fitzhugh, B, Butler, VL, Bovy, KM and Etnier, MA (2019) Human ecodynamics:

A perspective for the study of long-term change in socioecological systems.

Journal of Archaeological Science: Reports, 23: 1077-1094.

Held, D and Mcgrew, A (2000) The great globalization debate: an introduction. In: D Held and A Mcgrew (eds.) The Global Transformations Reader: an introduction to the globalization debate (2nd ed.). Cambridge, Malden: Blackwell Publishing, $1-50$.

Ingold, T (2007) Earth, Sky, Wind, and Weather. The Journal of the Royal Anthropological Institute of Great Britain and Ireland, 13: S19-S38. Ingold, T (2015) The life of lines. Abingdon, New York: Routledge 
Larkin, B (2013) The politics and poetics of infrastructure. Annual Review of Anthropology, 42: 327-343.

Schiffling, S and Valantasis Kanellos, N (2021a) How the Ever Given exposed the fragility of global supply chains. Meáin Náisiúnta Seirbhise Poibli na hÉireann/Ireland's National Public Service Media. Available at:

https:/www.rte.ie/brainstorm/2021/0406/1208101-ever-given-suez-canalblockage/ [accessed 17 September 2021].

Schiffling, S and Valantasis Kanellos, N (2021b) Ship Happens: Ever Given and Forgotten. World Infrastructure Journal. Available at: https://researchonline.ljmu.ac.uk/id/eprint/14747/ [accessed 17 September 2021]. Walker Vadillo, V (2021) Stranded at sea: seafaring in times of Covid-19. In: M Andrews (ed.) Multidisciplinary perspectives on the Covid-19 pandemic. Helsinki: Helsinki Collegium for Advanced Studies, Unigrafia, 34-37.

Handley, D (2021) Alternative fuels - what does the future hold for shipping? Watson, Farley \& Williams. Available at: https://www.wfw.com/articles/alternative-fuelswhat-does-the-future-hold-for-shipping/ [accessed 17 September 2021].

Westerdahl, C (1992) The maritime cultural landscape. The International Journal of Nautical Archaeology, 21(1): 5-14.

Wilkinson, D (2019) Towards an Archaeological Theory of Infrastructure. Journal of Archaeological Method and Theory, 26: 1216-1241. 